\title{
Amylase Inhibitors Produced by Streptomyces sp. No. 280
}

\author{
Takeshi TaJiri, Yojiro Koba and Seinosuke UEDA \\ Department of Food Science and Technology, Faculty of Agriculture, \\ Kyushu University, 10-1Hakozaki 6-chome, Higashi-ku, Fukuoka 812, Japan
}

Received May 7, 1982

\begin{abstract}
Fourteen kinds of amylase inhibitor (AI) were obtained by active carbon column chromatography and other procedures. The molecular weights of the AIs were estimated to be $310 \sim 1300$ by gel filtration. They seem to have $1 \sim 4$ glucose residues and one nitrogen per molecule. All the AIs have almost the same inhibitory activity against glucoamylase. High molecular weight AIs have much stronger activity toward $\alpha$-amylase and phosphorylase $a$ than low molecular weight AIs, but the latter have much stronger inhibitory activity toward sucrase and $\alpha$-glucosidase than the former. Four kinds of AI were hydrolyzed by $\beta$-amylase which changed their inhibitory activities.
\end{abstract}

Schmidt et al. ${ }^{1)}$ reported that amylase inhibitor BAYe 4609 was hydrolyzed by $\beta$ amylase, $\alpha$-amylase and mineral acid. Recently, Ueda and Marshall, ${ }^{2)}$ and Hidaka $e t$ $a l .^{3)}$ reported that the inhibitory activities of BAYe 4609 and BAYg 5421 toward $\alpha$-amylase, glucoamylase, sucrase and $\alpha$-glucosidase were changed after modification by some kinds of amylase.

In previous papers, ${ }^{4,5)}$ amylase inhibitors (AI) produced by Streptomyces sp. No. 280 were reported to consist of five kinds $\left(A_{1}, A_{2}\right.$, $B, B^{\prime}$ and C). After being hydrolyzed by $\alpha-$ amylase, $A_{1}$ and $A_{2}$ decreased in inhibitory activity toward $\alpha$-amylase but increased in inhibitory activity toward sucrase. Only $A_{1}$ was hydrolyzed by $\beta$-amylase with a change in inhibitory activity.

In this study, in order to further investigate the properties of AIs produced by Streptomyces sp. No. 280, we purified fourteen AIs and studied their inhibitory activities, modification by $\beta$-amylase and physicochemical properties.

\section{MATERIALS AND METHODS}

Microorganism. The organism used was identified as Streptomyces flavochromogenes, ${ }^{6)}$ it had been isolated in our laboratory from soil.
Cultivation. Flask cultivation for production of AIs was carried out at $30^{\circ} \mathrm{C}$ for 6 days in $500 \mathrm{ml}$ of $3 \%$ oatmeal medium on a rotary shaker. The $\mathrm{pH}$ was not adjusted.

Enzymes. Hog pancreatic $\alpha$-amylase, sweet potato $\beta$ amylase, rabbit muscle phosphorylase $a$ and yeast $\alpha$ glucosidase were purchased from Boehringer Mannheim $\mathrm{GmbH}$. Porcine small intestinal sucrase was prepared by freeze-thaw treatment according to the method of Marshall et al. ${ }^{7)}$ Glucoamylase from Rhizopus sp. was a commercial preparation from Amano Pharmaceutical Co.

Assay of inhibitory activities toward some carbohydrolases and phosphorylase a. Assays of inhibitory activities toward glucoamylase, ${ }^{8)}$ pancreatic $\alpha$-amylase, ${ }^{9)}$ muscle phosphorylase $a,{ }^{4)}$ small intestinal sucrase ${ }^{9)}$ and yeast $\alpha$ glucosidase $\mathrm{e}^{4)}$ were done according to the methods reported previously. One unit of inhibitory activity for each enzyme was defined as the decrease of one unit of each enzyme activity.

Active carbon column chromatography. In this study, we used active carbon column chromatography for purification of AIs. Active carbon for column chromatography (Nakarai Chemicals Ltd.) was agitated in $2 \mathrm{~N} \mathrm{HCl}$ for $2 \mathrm{hr}$ and washed with water. The active carbon was mixed with the same amount of Celite 545 (Nakarai Chemicals Ltd.) and packed into a column $(4.5 \times 40 \mathrm{~cm})$ equilibrated with water. An AI was applied on this column and washed with water, and then stepwise elution was done with $0 \sim 60 \%$ ethanol.

Paper chromatography and paper electrophoresis. Paper chromatography and paper electrophoresis of AIs were carried out as described in previous papers. ${ }^{5,9)}$ 
was applied on a column of Sephadex G-15 $(2.4 \times 140 \mathrm{~cm})$ equilibrated with $0.1 \mathrm{M}$ acetic acid. Elution was performed with the same acid solution at a flow rate of $12 \mathrm{ml} / \mathrm{hr}$, and $2.0 \mathrm{ml}$ fraction were collected. Maltooligosaccharides used as standards were prepared from maltodextrin (Hayashibara Biochemical Institute) by paper chromatography. The void volume of the column was measured with blue dextran.

High performance liquid chromatography (HPLC) of AIs. HPLC of AIs was carried out with a Hitachi 638-30 HPLC using a column $(4.6 \times 250 \mathrm{~mm})$ packed with Zorbax $\mathrm{NH}_{2}$ (Dupont). Elution was carried out with acetonitrilewater $(70: 30)$ at a flow rate of $1.0 \mathrm{ml} / \mathrm{min}$, and amylase inhibitors were detected with a Mass detector (Applied Chromatography System Ltd.).

Determination of glucose and total sugar. The glucose oxidase method ${ }^{10)}$ and phenol-sulfuric acid method ${ }^{11)}$ were used to determine glucose and total sugar, respectively.
Determination of reducing power of AIs. The SomogyiNelson method ${ }^{12,13)}$ was used to determine the reducing power of AIs with glucose as standard.

Determination of the reducing end of AIs. The reducing end of an AI was determined as follows: After reduction of the $\mathrm{AI}$ with $\mathrm{NaBH}_{4}$, the AI was hydrolyzed with $2 \mathrm{~N} \mathrm{HCl}$ at $100^{\circ} \mathrm{C}$ for $2 \mathrm{hr}$, and $\mathrm{Cl}^{-}$was removed with Amberlite IR-45 $\left(\mathrm{OH}^{-}\right)$. The AI hydrolyzate was analyzed as trimethylsilyl (TMS) derivatives by gas-liquid chromatography (GLC). GLC was carried out with a Nihondenshi GLC Model JGC-20 KFP.

\section{RESULTS}

\section{Preparation of AIs and hydrolyzed AIs}

1) Summary of purification. In order to get small molecule AIs, 6 days cultivation was done and followed by purification. Some of them were purified after hydrolysis of the crude AI with $2 \mathrm{~N}$ trifluoroacetic acid (TFA) at

Table I. Purification Procedures for Amylase Inhibitors

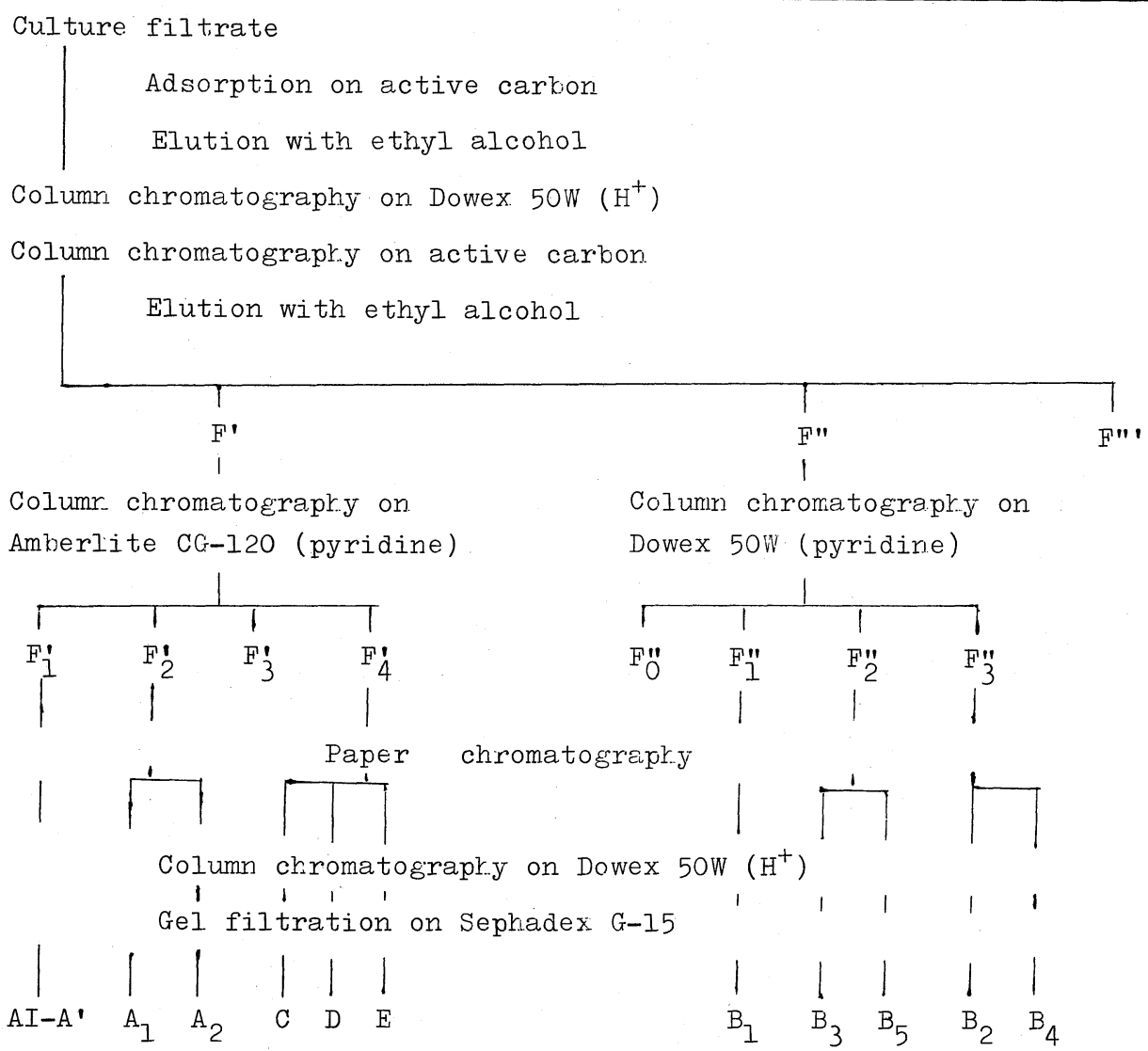


Table II. Purification Procedures for Hydrolyzed Amylase Inhibitors

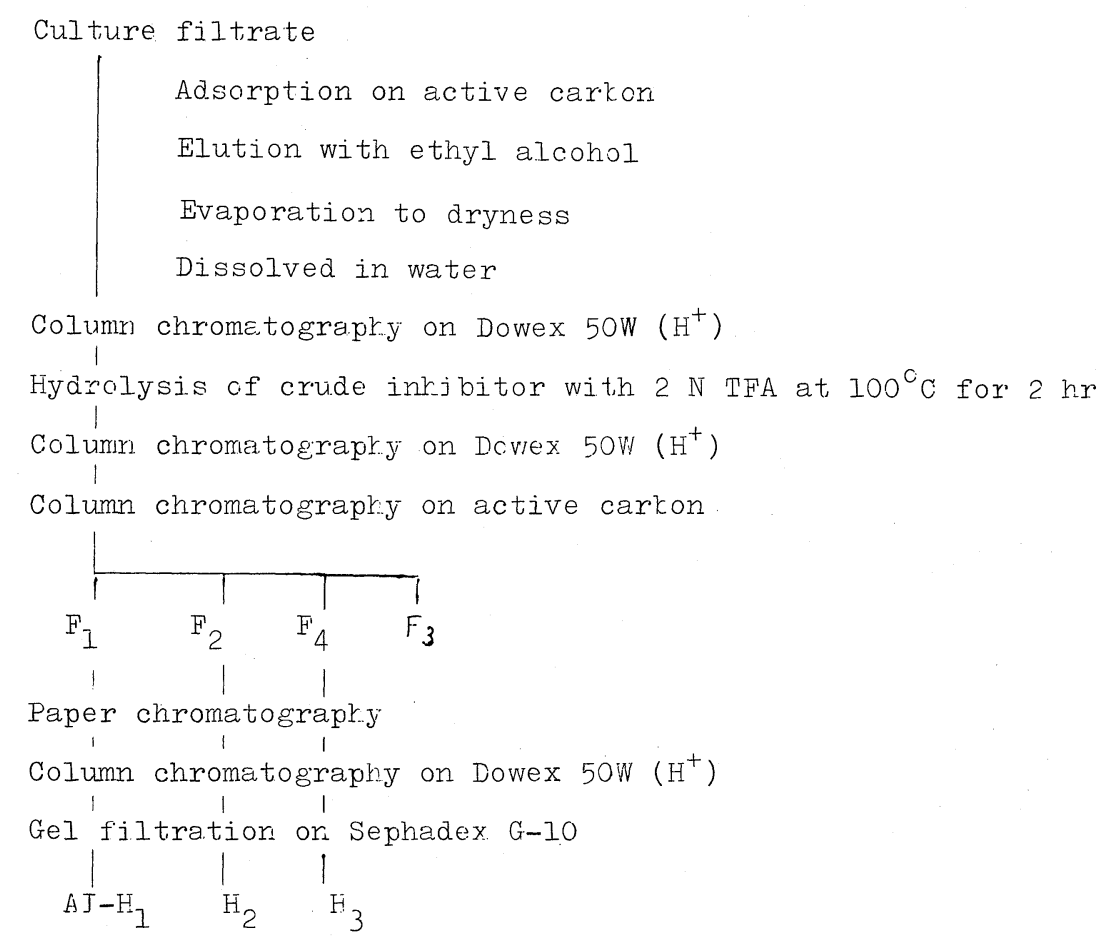

$100^{\circ} \mathrm{C}$ for $2 \mathrm{hr}$. Purification of an AI could be done efficiently by active carbon column chromatography in addition to the methods described in a previous paper. ${ }^{4)}$ The purification steps are shown in Tables I and II. The results of purification are summarized in Tables III and IV.

AI-A', $A_{1}, A_{2}, B_{1}, B_{2}, B_{3}, B_{4}, B_{5}, C, D$ and $E$ were separated from native $\mathrm{AI}$, and $\mathrm{AI}-\mathrm{H}_{1}, \mathrm{H}_{2}$ and $\mathrm{H}_{3}$ were separated from hydrolyzed AI.

2) Paper chromatography of purified AIs. The results of paper chromatography of purified AIs are shown in Fig. 1. Each AI had a different $R f$ value and gave a single spot.

3) Paper electrophoresis of purified AIs. On paper electrophoresis also, each AI gave a single spot and had a different $R_{\mathrm{m}}$, and a small molecular AI moved to the cathode much faster than a larger molecular AI.

4) HPLC of purified AIs. The retention times on HPLC of purified AIs are shown in Table V. Each AI gave a single peak and some of them showed the same retention time.

\section{Molecular weights of AIs}

The molecular weights of AIs were estimated by gel filtration. The results are shown in Table VI. The molecular weights of AIs were distributed from 310 to 1300 .

Ratio of total sugar content to reducing sugar content of AIs

The ratios are shown in Table VI.

Hydrolysis of AIs with $2 \mathrm{~N}$ TFA

AI-A', $A_{1}, B_{1}, B_{2}, B_{3}, B_{4}$ and $B_{5}$ were hydrolyzed with $2 \mathrm{~N}$ TFA at $100^{\circ} \mathrm{C}$ for $2 \mathrm{hr}$. The increase of reducing sugar in the reaction mixture stopped within $2 \mathrm{hr}$. The glucose content of the reaction mixture was determined by the glucose oxidase method. The increase of reducing sugar content agreed with the glucose content of the reaction mixture in each AI, so these AIs released only glucose on hydrolysis with TFA. 
Table III. Summary of Purification Procedures for Amylase Inhibitors

\begin{tabular}{|c|c|c|c|c|}
\hline & $\begin{array}{l}\text { Total sugar } \\
\text { (mg) }\end{array}$ & $\begin{array}{c}\mathrm{SA}^{*} \\
\left(\mathrm{IU}^{* *} / \mathrm{mg}\right)\end{array}$ & $\begin{array}{l}\text { Total activity } \\
\left(\mathrm{IU} \times 10^{-3}\right)\end{array}$ & $\begin{array}{l}\text { Yield } \\
(\%)\end{array}$ \\
\hline Crude AI & 61600 & 148 & 9100 & 100 \\
\hline Dowex 50W $\left(\mathrm{H}^{+}\right)$ & 12000 & 723 & 8680 & 95.3 \\
\hline \multicolumn{5}{|l|}{ Carbon column } \\
\hline $\mathrm{F}^{\prime}$ & 3440 & 933 & 3210 & 35.3 \\
\hline$F^{\prime \prime}$ & 2700 & 894 & 2414 & 26.5 \\
\hline $\mathrm{F}^{\prime \prime \prime} \longrightarrow * * *$ & 557 & 584 & 296 & 3.2 \\
\hline \multicolumn{5}{|c|}{ Dowex 50W (pyridine) } \\
\hline $\mathrm{F}_{0}^{\prime \prime * * *}$ & 37.0 & 55.7 & 2.1 & trace \\
\hline $\mathrm{F}_{1}^{\prime \prime}$ & 924 & 1340 & 1240 & 13.6 \\
\hline $\mathrm{F}_{2}^{\prime \prime}$ & 459 & 1136 & 521 & 5.7 \\
\hline$F_{3}^{\prime \prime}$ & 557 & 808 & 450 & 4.9 \\
\hline \multicolumn{5}{|l|}{ Amberlite (pyridine) } \\
\hline $\mathrm{F}_{1}^{\prime}$ & 82.6 & 402 & 33 & 0.4 \\
\hline $\mathrm{F}_{2}^{\prime}$ & 653 & 515 & 336 & 3.7 \\
\hline $\mathrm{F}_{3}^{\prime} * * *$ & 275 & 820 & 225 & 2.5 \\
\hline $\mathrm{F}_{4}^{\prime}$ & 213 & 1630 & 347 & 3.8 \\
\hline \multicolumn{5}{|c|}{ Paper chromatography } \\
\hline $\mathrm{F}_{1}^{\prime} \quad \mathrm{AI}-\mathrm{A}^{\prime}$ & 33.0 & 603 & 19.9 & 0.2 \\
\hline $\mathrm{F}_{2}^{\prime} \quad \mathrm{AI}-\mathrm{A}_{1}$ & 93.7 & 500 & 46.9 & 0.5 \\
\hline AI- $\mathrm{A}_{2}$ & 124 & 641 & 79.5 & 0.9 \\
\hline $\mathrm{F}_{4}^{\prime} \quad \mathrm{AI}-\mathrm{C}$ & 33.2 & 1820 & 60.4 & 0.7 \\
\hline AI-D & 29.5 & 1990 & 58.7 & 0.6 \\
\hline AI-E & 10.5 & 1820 & 19.1 & 0.2 \\
\hline $\mathrm{F}_{1}^{\prime \prime} \quad \mathrm{AI}-\mathrm{B}_{1}$ & 621 & 751 & 466 & 5.1 \\
\hline $\mathrm{F}_{2}^{\prime \prime} \quad \mathrm{AI}-\mathrm{B}_{3}$ & 135 & 1030 & 139 & 1.5 \\
\hline $\mathrm{AI}-\mathrm{B}_{5}$ & 54 & 1720 & 93.2 & 1.0 \\
\hline \multirow{3}{*}{\multicolumn{5}{|c|}{$\begin{aligned} \mathrm{F}_{3}^{\prime \prime} \quad & \mathrm{AI}-\mathrm{B}_{2} \\
& \mathrm{AI}-\mathrm{B}_{4} \\
\text { Dowex } & 50 \mathrm{~W}\left(\mathrm{H}^{+}\right)\end{aligned}$}} \\
\hline & & & & \\
\hline & & & & \\
\hline \multicolumn{5}{|l|}{ Sephadex G-15 } \\
\hline AI-A' & 10.5 & 856 & 9.0 & 0.1 \\
\hline $\mathrm{AI}-\mathrm{A}_{1}$ & 50.2 & 517 & 25.9 & 0.3 \\
\hline AI- $\mathrm{A}_{2}$ & 98.5 & 701 & 69.0 & 0.8 \\
\hline AI- $B_{1}$ & 339 & 899 & 304 & 3.4 \\
\hline $\mathrm{AI}-\mathrm{B}_{2}$ & 208 & 916 & 191 & 2.1 \\
\hline $\mathrm{AI}-\mathrm{B}_{3}$ & 50.9 & 1140 & 58.0 & 0.6 \\
\hline $\mathrm{AI}-\mathrm{B}_{4}$ & 23.0 & 1180 & 27.1 & 0.3 \\
\hline $\mathrm{AI}-\mathrm{B}_{5}$ & 32.7 & 1990 & 65.0 & 0.7 \\
\hline AI-C & 10.6 & 1960 & 20.7 & 0.2 \\
\hline AI-D & 15.2 & 2270 & 34.5 & 0.4 \\
\hline AI-E & 5.6 & 1930 & 10.8 & 0.1 \\
\hline
\end{tabular}

* SP, specific activity.

** IU, inhibitory activity units toward glucoamylase.

*** Further purification was not successful for these fractions.

Elemental analysis of AIs

The results of elemental analysis of AIs are shown in Table VI. From these results, it was considered that each AI has one nitrogen per molecule, so we estimated the molecular formula. The smallest AIs $\left(\mathrm{D}, \mathrm{H}_{1}, \mathrm{H}_{2}\right.$ and $\mathrm{H}_{3}$ ) have nineteen carbon atoms per molecule.
Inhibitory activity of AIs toward some carbohydrolases and phosphorylase a

In a previous paper, we compared the inhibitory activity of each AI as specific activity (IU/mg as glucose). ${ }^{5}$ So, in this study, we compared the activity as the inhibitory units per mmol of AI. The results of inhibitory 
Table IV. Summary of Purification Procedures for Hydrolyzed Amylase Inhibitors

\begin{tabular}{|c|c|c|c|c|}
\hline & $\begin{array}{l}\text { Total sugar } \\
\quad(\mathrm{mg})\end{array}$ & $\begin{array}{c}\mathrm{SA}^{*} \\
\left(\mathrm{IU} \mathrm{U}^{* *} / \mathrm{mg}\right)\end{array}$ & $\begin{array}{l}\text { Total activity } \\
\left(\mathrm{IU} \times 10^{-3}\right)\end{array}$ & $\begin{array}{l}\text { Yield } \\
(\%)\end{array}$ \\
\hline Crude AI & 2807 & 712 & 1990 & 100 \\
\hline \multicolumn{5}{|l|}{ Hydrolysis of AI } \\
\hline Dowex $50 \mathrm{~W}\left(\mathrm{H}^{+}\right)$ & 820 & 557 & 457 & 22.9 \\
\hline \multicolumn{5}{|l|}{ Carbon column } \\
\hline $\mathrm{F}_{1}$ & 39.8 & 422 & 17.6 & 0.9 \\
\hline $\mathrm{F}_{2}$ & 64.9 & 1530 & 99.4 & 5.0 \\
\hline $\mathrm{F}_{3} * * *$ & 81.0 & 632 & 51.2 & 2.6 \\
\hline $\mathrm{F}_{4}$ & 97.9 & 1280 & 125 & 6.3 \\
\hline \multicolumn{5}{|c|}{ Paper chromatography } \\
\hline $\mathrm{F}_{1} \quad \mathrm{AI}-\mathrm{H}_{1}$ & 33.0 & 795 & 26.2 & 1.3 \\
\hline $\mathrm{F}_{2} \quad \mathrm{AI}-\mathrm{H}_{2}$ & 50.5 & 1799 & 111 & 5.6 \\
\hline $\mathrm{F}_{4} \quad \mathrm{AI}-\mathrm{H}_{3}$ & 46.3 & 2230 & 103 & 5.2 \\
\hline \multicolumn{5}{|l|}{ Dowex 50W $\left(\mathrm{H}^{+}\right)$} \\
\hline $\mathrm{AI}-\mathrm{H}_{1}$ & 31.2 & 804 & 21.5 & 1.3 \\
\hline AI- $\mathrm{H}_{2}$ & 45.9 & 2530 & 121 & 6.0 \\
\hline $\mathrm{AI}-\mathrm{H}_{3}$ & 44.0 & 2150 & 94.6 & 4.7 \\
\hline \multicolumn{5}{|l|}{ Sephadex G-10 } \\
\hline $\mathrm{AI}-\mathrm{H}_{1}$ & 30.0 & 1010 & 30.3 & 1.5 \\
\hline $\mathrm{AI}-\mathrm{H}_{2}$ & 39.9 & 2920 & 116 & 5.8 \\
\hline $\mathrm{AI}-\mathrm{H}_{3}$ & 32.8 & 2830 & 92.8 & 6.6 \\
\hline
\end{tabular}

* SA, specific activity.

** IU, inhibitory activity units.

*** Further purification was not successful for this fraction.

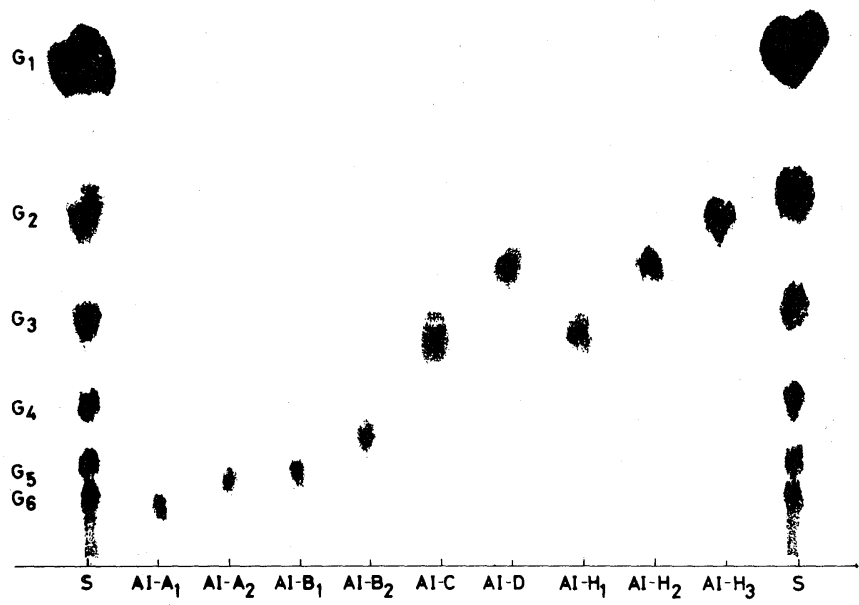

Fig. 1. Paper Chromatogram of Amylase Inhibitors. $\mathrm{S}$, maltooligosaccharides used as standards.

activity of AIs are shown in Table VII. All AIs have almost the same inhibitory activity toward glucoamylase. High molecular AIs inhibited $\alpha$-amylase much stronger than low molecular AIs and only high molecular AIs
(AI-A', $\mathrm{A}_{1}$ and $\mathrm{A}_{2}$ ) inhibited phosphorylase $a$, $A_{1}$ especially has a strong inhibitory activity. A moderate molecular AI $\left(\mathrm{AI}-\mathrm{B}_{5}\right)$ has a very strong inhibitory activity toward sucrase. High molecular AIs did not inhibit yeast $\alpha$-gluco- 
sidase, but low molecular AIs (AI-C, D, $\mathrm{H}_{1}$, $\mathrm{H}_{2}$ and $\mathrm{H}_{3}$ ) inhibited the enzyme, hydrolyzed AIs especially $\left(\mathrm{AI}-\mathrm{H}_{1}, \mathrm{H}_{2}\right.$ and $\left.\mathrm{H}_{3}\right)$ had a

TABle V. HPLC OF PURIFIEd AIs

Chromatographic conditions: column, Zorbax ${ }^{\mathrm{TM}} \mathrm{NH}_{2}$ $(4.6 \times 250 \mathrm{~mm})$; eluent, $\mathrm{CH}_{3} \mathrm{CN}-\mathrm{H}_{2} \mathrm{O}=70: 30$; flow rate, $1 \mathrm{ml} / \mathrm{min}$.

\begin{tabular}{cccc}
\hline Standard & $\begin{array}{c}\text { Retention } \\
\text { time }\end{array}$ & $\mathrm{AI}$ & $\begin{array}{c}\text { Retention } \\
\text { time }\end{array}$ \\
\hline $\mathrm{G}_{1}$ & 1.00 & $\mathrm{AI}-\mathrm{H}_{3}$ & 1.49 \\
$\mathrm{G}_{2}$ & 1.39 & $\mathrm{AI}-\mathrm{H}_{1}$ & 1.89 \\
$\mathrm{G}_{3}$ & 1.92 & $\mathrm{AI}-\mathrm{E}$ & 1.49 \\
$\mathrm{G}_{4}$ & 2.71 & $\mathrm{AI}-\mathrm{D}$ & 1.61 \\
$\mathrm{G}_{5}$ & 3.81 & $\mathrm{AI}-\mathrm{C}$ & 1.89 \\
$\mathrm{G}_{6}$ & 5.23 & $\mathrm{AI}-\mathrm{B}_{5}$ & 2.20 \\
& & $\mathrm{AI}-\mathrm{B}_{4}$ & 2.76 \\
& & $\mathrm{AI}-\mathrm{B}_{3}$ & 3.07 \\
& & $\mathrm{AI}-\mathrm{B}_{2}$ & 3.81 \\
& & $\mathrm{AI}-\mathrm{B}_{1}$ & 4.22 \\
& & $\mathrm{AI}-\mathrm{A}_{2}$ & 4.22 \\
& & $\mathrm{AI}-\mathrm{A}_{1}$ & 4.96 \\
\hline
\end{tabular}

strong inhibitory activity.

\section{Modification of AIs by $\beta$-amylase}

In our previous work, ${ }^{5)}$ only $\mathrm{A}_{1}$ was hydrolyzed by $\beta$-amylase. As we could obtain many newly purified AIs this time, we tried modification of these AIs by $\beta$-amylase. AI$A_{1}, B_{1}, B_{2}$ and $B_{4}$ were hydrolyzed by $\beta$ amylase, but other AIs (AI- $A_{2}, B_{3}, B_{5}$ and D) were not. The results are shown in Table VIII. AI- $A_{1}, B_{1}, B_{2}$ and $B_{4}$ released one mol of maltose and their inhibitory activities changed toward glucoamylase, $\alpha$-amylase and sucrase, as shown in Table VIII. From these results, it was assumed that these AIs have more than two glucose units at the nonreducing end.

\section{Determination of reducing end of AIs}

Determination of the reducing end of AIs $\left(\mathrm{AI}-\mathrm{A}_{1}, \mathrm{~A}_{2}, \mathrm{~B}_{1}, \mathrm{~B}_{2}, \mathrm{~B}_{3}, \mathrm{~B}_{4} \mathrm{~B}_{5}\right.$ and D) was tried. The TMS derivatives of hydrolyzates of re-

* As standards, a maltose series was used.

Table VI. Elemental Analysis of Purified Amylase Inhibitors AND HyDROLYZED AMYLASE INHIBITORS

\begin{tabular}{|c|c|c|c|c|c|}
\hline & $\begin{array}{l}\text { Elemental } \\
\text { analysis }\end{array}$ & $\begin{array}{l}\text { Molecular } \\
\text { formula }\end{array}$ & TS/RS* & M.W. ${ }^{a}$ & M.W. ${ }^{b}$ \\
\hline AI- $A_{1}$ & $\begin{array}{l}\text { C: } 42.28 \mathrm{~N}: 1.30 \\
\mathrm{H}: 6.48\end{array}$ & $\mathrm{C}_{38} \mathrm{H}_{69} \mathrm{NO}_{34}$ & 6.62 & 1083 & 1300 \\
\hline $\mathrm{AI}-\mathrm{A}_{2}$ & $\begin{array}{l}\text { C: } 43.33 \mathrm{~N}: 1.37 \\
\mathrm{H}: 6.46\end{array}$ & $\mathrm{C}_{37} \mathrm{H}_{65} \mathrm{NO}_{31}$ & 5.98 & 1019 & 1100 \\
\hline AI- $B_{1}$ & $\begin{array}{l}\text { C: } 42.94 \mathrm{~N}: 1.38 \\
\mathrm{H}: 6.56\end{array}$ & $\mathrm{C}_{36} \mathrm{H}_{66} \mathrm{NO}_{31}$ & 5.45 & 1008 & 1050 \\
\hline $\mathrm{AI}-\mathrm{B}_{2}$ & $\begin{array}{l}\text { C: } 44.04 \mathrm{~N}: 1.35 \\
\mathrm{H}: 6.68\end{array}$ & $\mathrm{C}_{36} \mathrm{H}_{69} \mathrm{NO}_{31}$ & 4.91 & 1011 & 900 \\
\hline $\mathrm{AI}-\mathrm{B}_{3}$ & $\begin{array}{l}\text { C: } 43.26 \mathrm{~N}: 1.61 \\
\mathrm{H}: 6.49\end{array}$ & $\mathrm{C}_{31} \mathrm{H}_{56} \mathrm{NO}_{26}$ & 4.17 & 858 & 800 \\
\hline $\mathrm{AI}-\mathrm{B}_{4}$ & $\begin{array}{l}\text { C: } 43.75 \mathrm{~N}: 1.60 \\
\mathrm{H}: 6.69\end{array}$ & $\mathrm{C}_{32} \mathrm{H}_{58} \mathrm{NO}_{26}$ & 3.39 & 872 & 600 \\
\hline $\mathrm{AI}-\mathrm{B}_{5}$ & $\begin{array}{l}\text { C: } 43.37 \mathrm{~N}: 1.94 \\
\mathrm{H}: 6.76\end{array}$ & $\mathrm{C}_{26} \mathrm{H}_{48} \mathrm{NO}_{21}$ & 2.95 & 710 & 600 \\
\hline AI-D & $\begin{array}{l}\text { C: } 43.18 \mathrm{~N}: 2.66 \\
\mathrm{H}: 6.68\end{array}$ & $\mathrm{C}_{19} \mathrm{H}_{35} \mathrm{NO}_{16}$ & 1.97 & 533 & 310 \\
\hline $\mathrm{AI}-\mathrm{H}_{1}$ & $\begin{array}{l}\text { C: } 41.72 \mathrm{~N}: 2.51 \\
\mathrm{H}: 7.03\end{array}$ & $\mathrm{C}_{19} \mathrm{H}_{39} \mathrm{NO}_{17}$ & 1.64 & 553 & 580 \\
\hline $\mathrm{AI}-\mathrm{H}_{2}$ & $\begin{array}{l}\text { C: } 45.38 \mathrm{~N}: 2.76 \\
\mathrm{H}: 7.07\end{array}$ & $\mathrm{C}_{19} \mathrm{H}_{36} \mathrm{NO}_{14}$ & 2.07 & 502 & 550 \\
\hline $\mathrm{AI}-\mathrm{H}_{z}$ & $\begin{array}{l}\text { C: } 43.96 \mathrm{~N}: 2.65 \\
\mathrm{H}: 7.15\end{array}$ & $\mathrm{C}_{19} \mathrm{H}_{33} \mathrm{NO}_{13}$ & 2.04 & 483 & 500 \\
\hline
\end{tabular}

* TS/RS, ratio of total sugar content to reducing sugar content.

a M.W. was calculated from molecular formula.

b M.W. was estimated by gel filtration on a Sephadex G-15 column. 
TABle VII. InHIBItory ACtivity of PURIFIEd InHIBItors*

\begin{tabular}{|c|c|c|c|c|c|c|c|}
\hline Enzyme & AI-A' & $\mathrm{AI}-\mathrm{A}_{1}$ & $\mathrm{AI}-\mathrm{A}_{2}$ & $A I-B_{1}$ & $\mathrm{AI}-\mathrm{B}_{2}$ & $\mathrm{AI}-\mathrm{B}_{3}$ & $\mathrm{AI}-\mathrm{B}_{4}$ \\
\hline $\begin{array}{l}\text { Glucoamylase } \\
\text { (Rhizopus sp.) }\end{array}$ & 38.2 & 19.0 & 23.3 & 27.2 & 25.0 & 26.4 & 22.2 \\
\hline $\begin{array}{l}\alpha \text {-Amylase } \\
\text { (Hog pancreas) }\end{array}$ & 39.6 & 42.3 & 13.3 & 2.31 & 1.73 & 0.93 & 5.78 \\
\hline $\begin{array}{l}\text { Sucrase } \\
\text { (Hog intestine) }\end{array}$ & 0.07 & 0.01 & 0.03 & 0.11 & 0.25 & 0.22 & 0.05 \\
\hline $\begin{array}{l}\text { Phosphorylase } a \\
\text { (Rabbit muscle) }\end{array}$ & 5.81 & 140.6 & 1.68 & 0 & 0 & 0 & 0 \\
\hline $\begin{array}{l}\alpha \text {-Glucosidase } \\
\text { (Yeast) }\end{array}$ & 0 & 0 & 0 & 0 & 0 & 0 & 0 \\
\hline Enzyme & $A I-B_{5}$ & AI-C & AI-D & AI-E & $\mathrm{AI}-\mathrm{H}_{1}$ & AI- $\mathrm{H}_{2}$ & $\mathrm{AI}-\mathrm{H}_{3}$ \\
\hline $\begin{array}{l}\text { Glucoamylase } \\
\text { (Rhizopus sp.) }\end{array}$ & 32.6 & 25.6 & 24.9 & 21.7 & 9.22 & 33.6 & 32.1 \\
\hline $\begin{array}{l}\alpha \text {-Amylase } \\
\text { (Hog pancreas) }\end{array}$ & 0.44 & 0.83 & 0.47 & 1.07 & 0.35 & 0.20 & 0.81 \\
\hline $\begin{array}{l}\text { Sucrase } \\
\text { (Hog intestine) }\end{array}$ & 0.69 & 0.11 & 0.27 & 0.05 & trace & 0.06 & 0.01 \\
\hline $\begin{array}{l}\text { Phosphorylase } a \\
\text { (Rabbit muscle) }\end{array}$ & 0 & 0 & 0 & 0 & 0 & 0 & 0 \\
\hline $\begin{array}{l}\alpha \text {-Glucosidase } \\
\text { (Yeast) }\end{array}$ & 0 & 0.13 & 0.06 & 0.13 & 0.38 & 1.46 & 2.37 \\
\hline
\end{tabular}

* These figures are inhibitory activity $(\mathrm{IU} / \mathrm{m} \mathrm{mol})$.

Table VIII. Modification of Amylase Inhibitors by $\beta$-AmylaSe

\begin{tabular}{|c|c|c|c|c|}
\hline \multirow{2}{*}{ AI } & \multirow{2}{*}{$\begin{array}{l}\text { Increase of } \\
\text { reducing sugar } \\
\text { (fold) }\end{array}$} & \multicolumn{3}{|c|}{ Residual inhibitory activity ( $\%$ ) } \\
\hline & & Glucoamylase & $\alpha$-Amylase & Sucrase \\
\hline $\mathrm{AI}-\mathrm{A}_{1}$ & 1.86 & 100 & 5.20 & 100 \\
\hline $\mathrm{AI}-\mathrm{B}_{1}$ & 2.00 & 43.5 & 46.9 & 93.0 \\
\hline $\mathrm{AI}-\mathrm{B}_{2}$ & 2.19 & 21.9 & 46.9 & 510 \\
\hline $\mathrm{AI}-\mathrm{B}_{4}$ & 2.01 & 100 & 28.6 & 46.0 \\
\hline
\end{tabular}

duced AIs gave peaks of $\alpha$-D-glucose, sorbitol and $\beta$-D-glucose (AI-A $A_{1}, A_{2}, B_{1}, B_{2}, B_{3}, B_{4}$ and $B_{5}$ ) or sorbitol only (AI-D). It became apparent that these AIs have one glucose unit at the reducing end.

\section{DISCUSSION}

Fourteen purified AIs were obtained by active carbon column chromatography, Dowex $50 \mathrm{~W}$ column chromatography, paper chromatography, etc. Each of these AIs gave a single spot or single peak on paper chromatography, paper electrophoresis and HPLC. These AIs have different inhibitory activities toward hog pancreatic $\alpha$-amylase, hog small intestine sucrase, rabbit muscle phosphorylase $a$ and yeast $\alpha$-glucosidase. However, all the AIs have almost the same inhibitory activity toward glucoamylase (19 $38 \mathrm{IU} / \mathrm{mmol})$. High molecular AIs inhibited $\alpha$-amylase much stronger than low molecular AIs, and after modification of AIs with amylase or organic acid, the inhibitory activity toward $\alpha$-amylase decreased. Such results were seen for every AI. Schmidt $e t$ $a l{ }^{1)}$ reported that the inhibitory activity to- 
ward sucrase was increased after hydrolysis with mineral acid. In this study, a moderate molecular AI (AI-B $)_{5}$ was shown to have the strongest inhibitory activity toward sucrase (0.69 IU $/ \mathrm{mmol})$ but $\mathrm{AI}-\mathrm{B}_{2}$ modified by $\beta$ amylase had 5 times higher inhibitory activity toward sucrase than that of original AI- $\mathrm{B}_{2}$ (modified AI-B ${ }_{2}, 1.28 \mathrm{IU} / \mathrm{mmol}$; original AI$\mathrm{B}_{2}, 0.25 \mathrm{IU} / \mathrm{mmol}$ ). (Table VIII and IX). AI$\mathrm{A}^{\prime}, \mathrm{A}_{1}$ and $\mathrm{A}_{2}$ inhibited phosphorylase $a$, and then after modification of them with amylase or mineral acid, the inhibitory activity toward phosphorylase $a$ was lost. AI-A', $\mathrm{A}_{1}, \mathrm{~A}_{2}, \mathrm{~B}_{1}$, $B_{2}, B_{3}, B_{4}$ and $B_{5}$ did not inhibit yeast $\alpha-$ glucosidase, but AI-C, D, E, $\mathrm{H}_{1}, \mathrm{H}_{2}$ and $\mathrm{H}_{3}$ inhibited this enzyme.

We thought that the inhibitors produced by Streptomyces sp. No. 280 were kinds of glycopeptides in the early study, but now we can't confirm the presence of glycopeptideinhibitors. This may be because purification of the inhibitors was insufficient. However, there is also another possibility, that is, the nature of this strain changed and the strain became unable to produce the glycopeptide-inhibitors. Because in the early study ${ }^{8)}$ we didn't find inhibitors which were hydrolyzed by $\beta$-amylase, but now some inhibitors were found to be sensitive to $\beta$-amylase. In the previous studies, ${ }^{4,5)}$ only $\mathrm{A}_{1}$ was hydrolyzed by $\beta$-amylase, but in this study, AI- $A_{1}, B_{1}, B_{2}$ and $B_{4}$ were hydrolyzed by this enzyme. On the other hand, $\mathrm{A}_{2}, \mathrm{~B}, \mathrm{~B}^{\prime}$ and $\mathrm{C}$ in the previous studies were not hydrolyzed by $\beta$-amylase as $\mathrm{AI}-\mathrm{A}_{2}$, $B_{3}, B_{5}$ and $D$ were not in this study.

We think that the structure of the inhibitors seems to be similar to that of reported oligosaccharide-inhibitors, ${ }^{2,14,15)}$ that is, they consist mainly of glucose with a mixture of an $\mathrm{N}$-compound which has 13 carbon atoms and a glucose. Because the compounds obtained on hydrolysis of the inhibitors with TFA had 19 carbon atoms, and the formula of $\mathrm{AI}-\mathrm{H}_{3}$ was $\mathrm{C}_{19} \mathrm{H}_{33} \mathrm{NO}_{13}$. The differences of the fourteen purified AIs may be caused by their different glucose chain lengths. However, some inhibitors produced by Streptomyces sp. No. 280 have properties different from the reported oligosaccharide-inhibitors. That is to say, AI$\mathrm{A}_{2}, \mathrm{~B}_{3}, \mathrm{~B}_{4}$ and $\mathrm{D}$ aren't hydrolyzed by $\beta$ amylase, and AI-A', $A_{1}$ and $A_{2}$ inhibit phosphorylase $a$. From these results, it is suggested that these inhibitors have different structures from the reported oligosaccharide-inhibitors.

We don't know why in AI-A 2 , for instance, the number of glucoses estimated from the ratio of total sugar content to reducing sugar content in Table VI seems to be 6 , but that from the molecular formula seems to be 4 if the $\mathrm{N}$-compound has 13 carbon atoms. The total sugar content value obtained by the phenol-sulfuric acid method for these inhibitors may be larger than the actual sugar content.

From these results, it is suggested that the inhibitory activity of AIs toward these carbohydrolases and phosphorylase $a$ is closely related to the glucose chain structure of each AI. Therefore, it is necessary to reveal the detailed relationship between the inhibitory activity and the glucose chain structure of an AI. More detailed investigation of the strucure of AIs will be reported elsewhere.

\section{REFERENCES}

1) D. D. Schmidt, W. Frommer, B. Junge, L. Muller, W. Wingender and E. Truscheit, Naturwissenschaften, 64, 535 (1977).

2) S. Ueda and J. J. Marshall, J. Jpn. Soc. Starch Sci., 26, 128 (1979).

3) H. Hidaka, T. Takaya and J. J. Marshall, J. Jpn. Soc. Starch Sci., 27, 114 (1980).

4) S. Ueda, Y. Koba and H. Chaen, Carbohydr. Res., 61, 253 (1978).

5) H. Nakano, T. Tajiri, Y. Koba and S. Ueda, Agric. Biol. Chem., 45, 1053 (1981).

6) M. Yagisawa, K. Kato, Y. Koba and S. Ueda, J. Ferment. Technol., 50, 572 (1972).

7) J. J. Marshall, C. M. Sturgeon and W. J. Whelan, Anal. Biochem., 82, 435 (1977).

8) S. Ueda and Y. Koba, Agric. Biol. Chem., 37, 2025 (1973).

9) H. Chaen and S. Ueda, Agric. Biol. Chem., 43, 2265 (1979).

10) M. Dubois, K. A. Gilles, J. K. Hamilton, P. A. Rebers and F. Smith, Anal. Chem., 28, 350 (1956).

11) N. M. Papadopoulos and W. C. Hess, Arch. Biochem. Biophys., 88, 167 (1960).

12) N. Nelson, J. Biol. Chem., 153, 375 (1944). 
13) M. Somogyi, J. Biol. Chem., 160, 69 (1945).

14) K. Ohyama and S. Murao, Agric. Biol. Chem., 41, 2221 (1977).
15) S. Namiki, K. Kangouri, T. Nagata, H. Hara, E. Mori, S. Ohmura and M. Ohzeki, J. Jpn. Soc. Starch Sci., 26, 134 (1979). 